\title{
乳癌患者に打ける細胞性免疫能に関する研究
}

\author{
東京女子医科大学第二病院外科（部長：榊原 宣教授） \\ 芳 賀 陽子

\section{CLINICAL STUDY ON CELL-MEDIATED IMMUNITY IN BREAST CANCER PATIENTS}

Yoko HAGA

Department of Surgery, Tokyo Women's Medical College Daini-Byoin Hospital

(Director : Prof. Noburu SAKAKIBARA)

乳癌患者の細胞性免度能を末梢血リンバ球数, $\mathrm{T}$-細胞比, B-細胞比, IgG-FcR ${ }^{+} \mathrm{T}$-細 胞比，PHAによるリンパ球幼若化反応（SI 值)などを用いて明らかにし，まず癌腫と進 行度との関倸, ついで進行度を規定する因子との関保について検討した。ささらにこの細 胞性免疫能の術前・術後にわたる経時的変動についても検索し, これが乳癌患者の治療 経過にどのようにかかわっているのか，またいかなる指針となりらるかなどについて検 討をこころみた。ささらに外科手術との関係では手術侵留が患者の細胞性免度能におよば す影響について検討した。

進行度別にみた各バラメーターの術前値では, 末梢血リンパ球数, T-細胞比は stage I, II, III に比較して stage IV で減少あるいは低下を示したが，B-細胞比， Tr 細胞比で は stage I, II に比較して， stage III, IV で高值を示した。また，末梢血リンパ球のPHA 幼若化反応の SI 值は病期の進行にしたがい低下した。

進行度を規定する因子別にみれば，遠隔転移のあるものは免疫能の低下を認めたか， 畽瘤径は直接免疫能に影製せず,リンパ節転移が細胞性免疫能の低下にむっとも関与す ることが示唆された。

術前・㭪後にわたる経時的変動の検索から, 末梢血リンハ球の PHA 幼若化反応の SI 值が細胞性免疫能の動向や臨床経過をるっとも鋭敏に反映し, 再発予知の指標とすなり らると思われた。

また，手術唚㦒の影響を手術術式別でみれば，いずれの術式でる細胞性免疫能は㧕制 されるが，その程度は定型手術, 縮小手術に比較して拡大手術群は著明であった。

索引用語：乳癌, 細胞性免疫能

\section{第 1 章 緒 言}

乳癌の外科的治療は, 1891年に Halsted が根治手術 を報告して以来, 治療成績の向上をめざした拡大根治 手術が提唱され，一方合理性を追求した縮小手術がこ ころみられるなど，手術術式を中心とした工夫や改善 がなされているいー3).

しかし，いずれの術式にせよ，手術のみによる治療 では比較的早期に発見されたと考えられる $\mathrm{N}_{0}$ 症例, すなわちリンハ節転移のない症例においてさえ $10 \%$ 前
後の主として血行性転移による再発がみられている。 乳癌の治療成績をさらに向上させるためには，この よらな術後の転移・再発の防止が重要であることは論 をまたない，このため局所療法である外科手術に加え て, 全身療法である化学療法, 免疫療法などの補助㞠 法が多くの施設で積極的に行われ( 乳癌治療の原 則とされるにいたっている。

他方, とトの癌腫においてす危度学的応答が営まれ

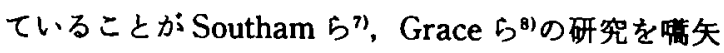


として明らかにされたが，癌患者の免疫能を正確に把 握することは，兔疫療法との関連もあって，癌の治療 上極めて重要である.とくに細胞性免疫能が注目され， 種々の免疫学的バラメーターを駆使した詳細な検討が 行われている活

乳癌患者等おいても，このような観点から主として 非特異的細胞性免疫能に関して検索されている が(5)16)，多くは進行度との関連を論しているのみであ り，その進行度を規定する因子との関係，さらには治 療に直結する外科手術や補助療法による变動などを明 らかにした報告はない上らである、すなわち，検索さ れた免疫能が乳癌の治療指針としてあまり役立ってい ない現状であるように思われる。

乳癌患者の非特異的細胞性免疫能に関してこのよう な諸点を明確にできれば，その成績をふまえて補助療 法を合理的に行らことが可能となり，ひいては治療成 績の向上につながるものと考えられよう.

そこで，乳癌患者に拈ける非特異的細胞性免疫能を 末梢血リンパ球数， $\mathrm{T}$-細胞比，B-細胞比，IgG-FcR ${ }^{+}$ $\mathrm{T}$-細胞比, PHAによるリンバ球幼若化反応 (SI 值) などを用いて明らかにし，まず癌腫の進行度との関保， ついで進行度を規定する因子との関係について検討し た。さらにこの細胞性免疫能の術前・術後にわたる释 時的変動についても検索し, これが乳癌患者の治療程 過にどのよらにかかわっているのか，またいかなる指 針となりらるのかなどについて検討をこころみた。そ して外科手術との関俰では，手術侵裝が患者の細胞性 免疫能におよぼす影響について検討した。

\section{第 2 章 検索対象およひ検索方法}

\section{第 1 節 検索対象}

1977年 1 月より1982年10月までに東京女子医科大学 第二病院外科で手術, 補助免疫化学療法がなされ, 術 前・術後にわたる非特異的細胞性免度能が明らかな乳 癌患者 80 症例（乳癌取扱い規的 ${ }^{17) て ゙ い 5 ~ s t a g e ~ I ~} 53$ 症 例, stage II 11 症例, stage III 8 症例, stage IV 8 症 例,なされた手術術式別では定型的乳房切断術66症例, 抬大根治手術 6 症例, 縮小手術 8 症例)を対象とした。 なおこのらち再発は, stage I, II に6 例, stage III, IV に 4 例みられた。

補助免疫化学㞠法は, 寛解強化法として, Mitomycin C 訹後 1 カ月以内に間歇投与で総量1 $\mathrm{mg} / \mathrm{kg}$, 維持療法として FT-207 600 mg/day を連日経 口投与する化学療法に，免疫賦活剤として PSK 3.0g/ dayの連日経口投与, OK-432の感作投与後 $2.0 \mathrm{KE} /$ weekの間歇投与を併用した。

\section{第 2 筑 検象方法}

末梢血 リンパ球数, T-細胞比, B-細胞比, IgG-FcR ${ }^{+}$ $\mathrm{T}$-細胞比, PHA によるリン八球幼若化反応 (SI 值), 乳癌の病理組織学的進行度を規定する因子などについ て, 次の上らな方法で恰索を行った。

\section{1. 末梢血リンハ球数の测定}

ヘハシリン加末梢血の白血球数を Microcounter cc120 (東覀医用䉓子株式会社製)で測定後, 同血液叙洙 標本をライトギムザ染色にて1,000倍で鏡検、リンパ球 数の百分率を求め，両者を乗じて $1 \mathrm{~mm}^{3}$ 中のリンパ球 数を算定した。なお正常のリンパ球数は $1 \mathrm{~mm}^{3}$ 中, 1,500 3,000とした.

\section{2. 末梢血リン八球浮遊流の作成}

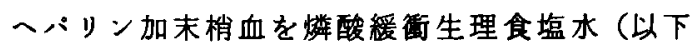
PBS) で 2 倍に希釈し，Ficoll-conray 比重遠心法 (比 重1.077) ${ }^{18)}$ によりンンバ球を分離した. PBSで 3 回洗 净したのち, 10\%牛胎児血清加 RPMI-1640を加えてリ ンパ球数 $1 \times 10^{6} / \mathrm{ml}$ および $5 \times 10^{5} / \mathrm{ml}$ となるように調 整し，リンハ球浮遊液として以下の測定に用いた。

\section{3. $\mathrm{T}-$ 細胞比の測定}

T-細胞比は檽らの測定法 ${ }^{19220)} に$ 準したマイクロプ レート法で測定した。すなわち, poly-L-lysine 処理し たファルコン社製\#3034マイクロテストプレートの ウェルに, $1 \times 10^{6} / \mathrm{ml}$ に調整したリンハ球浮遊液を $1 \mu 1$ つつ加え，30分間静置したのち洗浄，さらに牛胎児血 清 $10 \mu 1$ を加え, 同じょらに30分間静置して洗浄した。 ついで赤血球数 $2 \times 10^{8} / \mathrm{ml}$ に調整した neuraminidase 処理ヒッジ赤血球（日本抗体研究所製）を10 $\mu 1$ 加え, 100G で 5 分間遠心した. その後ブレートを反転して30 分間静置後, PBSに30分間漫して洗浄し,プリリアン トクレシールブルーで固定染色した，400倍で鏡検し， ヒッジ赤血球が 4 個以上付着したリンパ球（Eロゼッ 卜形成細胞）を T-細胞とし，300個のリンハ、球中の百 分率で表わした。な拝常の $\mathrm{T}$-細胞比は76 86\%と した.

\section{B-細胞比の測定}

B-細胞比も檑らのマイクロプレート法19120) で剆定 した.同しく poly-L-lysine 処理したマイクロテストブ レートのウェルに, $1 \times 10^{6} / \mathrm{ml}$ に調整したリンハ球浮 遊夜を $1 \mu 1$ つ’加之, 30 分間静置したのち洗浄, さら に牛胎児血清 $10 \mu \mathrm{l}$ を加元, また40分間静置して洗浄し た. ついで赤血球数 $2 \times 10^{8} / \mathrm{ml}$ に調整した IgM 感作補 体結合ヒッシ赤血球 (日本抗体研究所製) $10 \mu 1$ 加光, 
$37^{\circ} \mathrm{C} て ゙ 30$ 分間静置した。 その後ブレートを反転して 37 Cで30分間静置，そしてPBSに30分間浸して洗浄 し，ブリリフントクレシールブルーで固定染色した。

T一細胞の場合と同じ400倍で鏡検し，ヒッシ赤血球が4 個以上付着したリンパ球（EACロビット形成細胞）を B-細胞とし，300個のリンハ・球中の百分率で表わした。 正常のB-細胞比は8 $16 \%$ とした。なおリンハ球中 に混入した顕粒球はベルオキシダーセ陽性細胞として 補正した。

\section{IgG-FcR ${ }^{+} \mathbf{T}$-細胞比の測定}

IgG-FcR ${ }^{+} \mathrm{T}-$ 細胞比（以下 $\mathrm{T} \gamma$ 細胞）比は新保 ${ }^{21)}$ の方法を改良したマイクロブレート法で行った。すな わち，T，B-細胞比測定の場合と同しく poly-L-lysine 処理したマイクロブレートのウェルに, $1 \times 10^{6} / \mathrm{ml} に$ 調整したリンバ球浮遊液を $1 \mu 1$ つつ加え，30分間静置 したのち洗浄，さらに牛胎児血清 $10 \mu 1$ を加え，また 30 分間静置して洗净した。 ついで赤血球数 $2 \times 10^{8} / \mathrm{ml}$ K 調整したIgG 感作 慗)を $10 \mu \mathrm{l}$ 加え, $37^{\circ} \mathrm{C} て ゙ 60$ 分間静置した. その後プレー 卜を反転して $37^{\circ} \mathrm{C} て ゙ 30$ 分間静置, そしてPBSに30分 間浸して洗浄した。つついて赤血球数 $2 \times 10^{\mathrm{B}} / \mathrm{ml}$ に調 整した neuraminidase 処理ヒッシ赤血球（日本抗体研 究所製)を $10 \mu 1$ 加方，100Gで 5 分間遠心した。 その後 ブレートを反転し30分く静置した後PBSに30分間浸 して洗浄, プリリアントクレシールブルーで固定染色 した. 400 倍で鏡検し，ニワトリ赤血球か～ 2 個以上，七 ッジ赤血球が 4 個以上付着したリンパ球（ダブルロ ゼット形成細胞）を $\mathrm{T} \boldsymbol{\gamma}$ 細胞, ヒッジ赤血球が 4 個以

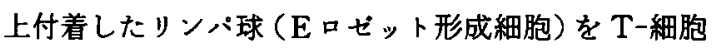
とし、これらを合計 300 個計測して $\mathrm{T} \gamma$ 細胞比は下記の 式より算出した。

$\mathrm{T} \gamma$ 紐胞比 $(\%)=$

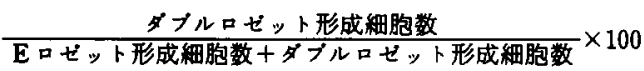

なお正常の $\mathrm{T} \gamma$ 細胞比は8～20\%とした。

6. PHAによるリン八球幼若化反応 (SI 值) の测定 ファルコン社製\#3042カルチャープレートのウェル に, $5 \times 10^{5} / \mathrm{ml}$ に調整したリンバ球浮遊液を $200 \mu \mathrm{l}$ つトリプリケイトに加えた. PHA (phytohemagg. lutinin) はPHA-P (Difco Lab.製)を用い，200 $\mu \mathrm{g} / \mathrm{ml}$ に調整してPHA 刺激群の各ウェルに20 $\mu 1$ つつ添加 した. 一方, 非刺潄群のウェルには10\%牛胎児血清加 RP MI-1640を各20 1 1 加えるのみとした．そして5\%炭 酸ガス培盖器で $37^{\circ} \mathrm{C} ， 72$ 時間培羡し, 培羡終了 24 時間
前に ${ }^{3} \mathrm{H}$-Thymidineを各ウェルあたり $0.5 \mu \mathrm{ci} / \mathrm{ml}$ と なるよら調整して加えた。回收はセルハーベスターを 使用し，放射活性の測定は液体シンチレーションカウ ンター(LKB 社製)を使用して c.p.m.を測定した. 3 つのウェルの平均値をもって PHA 刺激群, 非刺激群 の幼若化能とし, stimulation Index (以下 SI 値) は下 記の式より算出した。

SI 値 $=\frac{\text { PHA 刺激群 (c.p.m.) }}{\text { PHA 非激群 (c.p.m.) }}$

な抢正常の SI 值は105〜225とした.

7. 乳癌の進行度を規定する因子なと

乳癌の $\mathrm{Tnm}$ 病期別進行度および進行度を規定する 因子, すなわち腫瘤の最大径や拆かり $\mathrm{T}$, 組織学的リ ンバ節転移度 $\mathrm{n}$, 遠隔転移の有無 $\mathrm{m}$ などについて, 乳癌 取扱い規約 ${ }^{177}$ に基ついて記録し，対比した。

\section{第 3 童 検索成䋶}

第 1 節 術前の非特異的細胞性免废能

1. 免疫学的パラメーターと Tnm 病期分類による 進行度（stage）との関係

1）末梢血リンハ球数

術前の末梢血リン八球数と乳癌の Tnm 病期分類に よる進行度との関係は图 1 に示すとおりである.

末梢血リンパ球について Tnm 病期分類による進行 度別にみると, stage I $1,928.7 \pm 73.6\left(/ \mathrm{mm}^{3}\right)$, stage II $1,971.1 \pm 142.2$, stage III $1,840.8 \pm 127.8$, stage

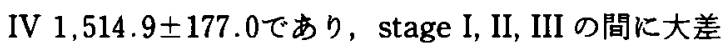
はないが, stage IVでは減少した。

2) $\mathrm{T}$-細胞比, B-細胞比, $\mathrm{T} \gamma$ 細胞比

術前の $\mathrm{T}$-細胞比拉上び B-細胞比, $\mathrm{T} \gamma$ 細胞比と乳

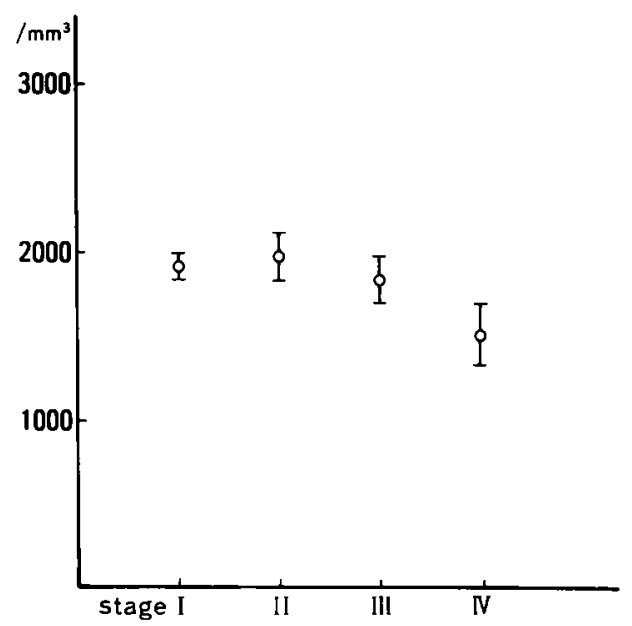

図 1 末梢血リンパ球数 
癌の Tnm 病期分類による進行度との関釈は图 2 にお よび図 3 に示すとおりである。

T-細胞比についてみると， stage I 80.8土1.5（\%)， stage II $80.5 \pm 4.9$, stage III $79.0 \pm 3.0$, stage IV $73.0 \pm 3.9$ であり, stage I, II, III の間に大美はないが, stage IVでは低値を示した。

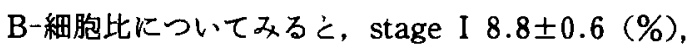
stage II $8.7 \pm 1.6$, stage III $11.1 \pm 2.3$, stage IV $10.1 \pm 1.1 て ゙ あ り$ 病期の進行にしたがい高值を示す傾 向を認めた。

$\mathrm{T} \gamma$ 細胞比についてみると, stage I 8.1 $\pm 0.9(\%)$ ， stage II $9.2 \pm 2.8$, stage III $14.6 \pm 1.6$, stage IV $11.9 \pm 3.5$ であり,これも病期の進行にしたがい高值を 示寸傾向を認めた。

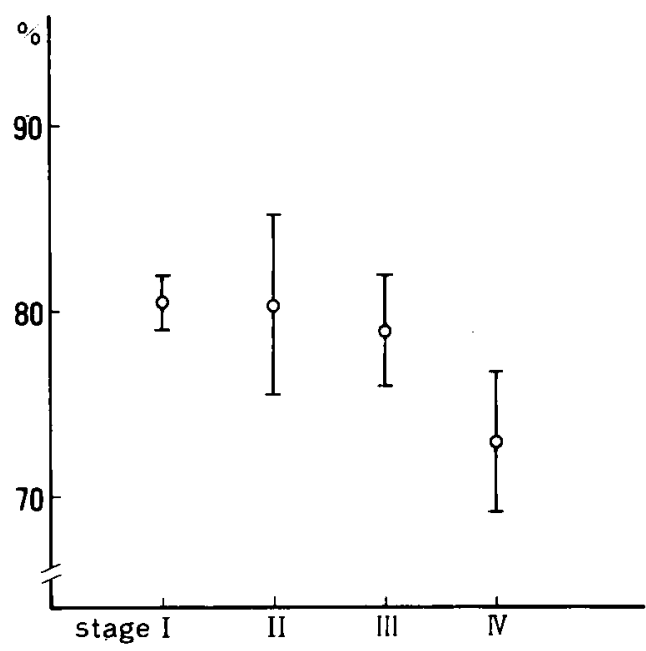

図 2 T-細胞比

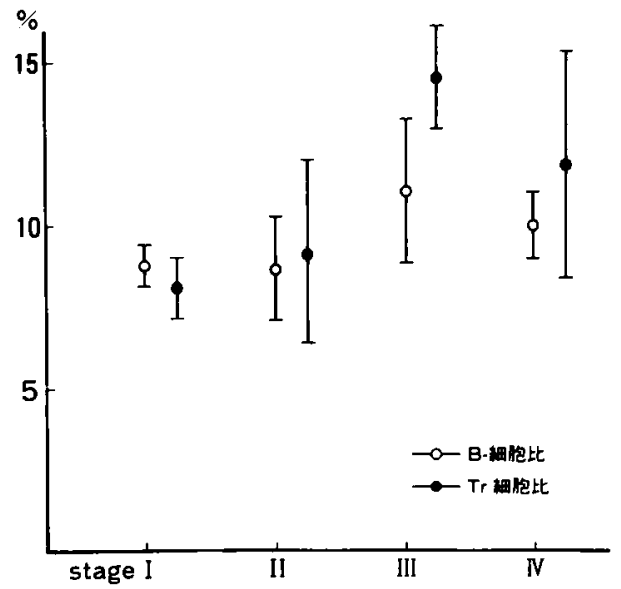

目 3 B-細胞比・ $\mathbf{T} \gamma$ 細胞比
3) PHA 幼若化反応 (SI 值)

術前の PHA 幼若化反応のSI 值と乳癌の Tnm 病 期分類進行度との関係は图 4 に示すとおりである.

SI 值についてみると, stage I 207.5 \pm 34.2 , stage II $204.0 \pm 64.2$, stage III $152.3 \pm 71.6$, stage IV $106.0 \pm 47.3 て ゙ あ り$, 病期の進行にしたがって低下し た.

2. 免疫学的パラメーターと厤（T）との関係

1) 末梢血リンハ球数

術前の末梢血リンパ球数と乳癌の腫瘤との関係は図 5 に示すとおりである。

末梢血リンパ球数について腫瘤の大きさき拗がり別 にみると, $T_{1} 1,889.1 \pm 113.6\left(/ \mathrm{mm}^{3}\right), T_{2} 1,925.7 \pm$

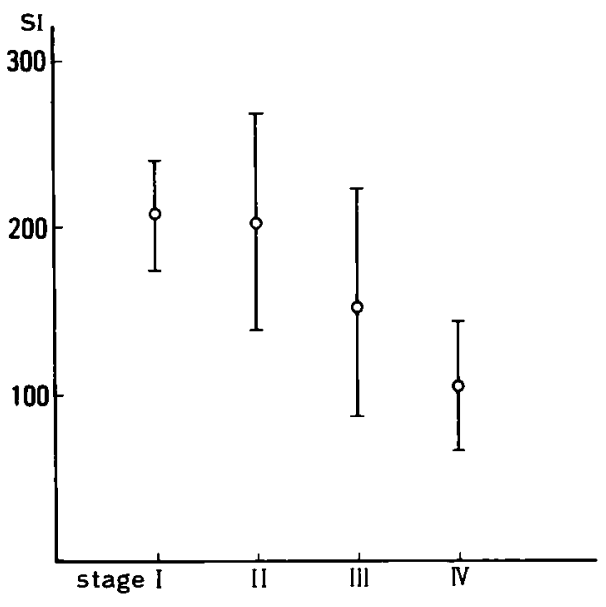

図 4 PHA 幼若化反応（SI 值）

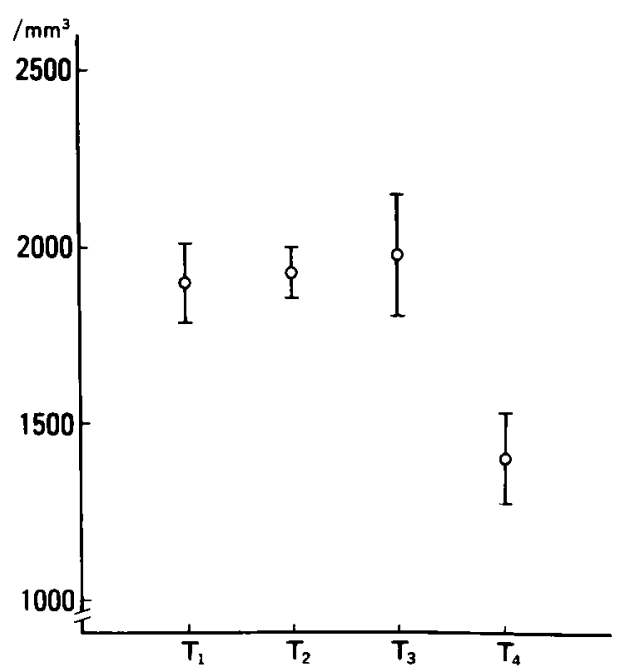

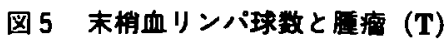




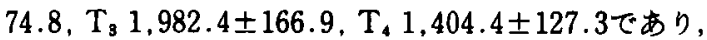
$\mathrm{T}_{1,2,3}$ の間に大差はないが, $\mathrm{T}_{4}$ では著明に減少した。

2） T-細胞比おょび B-細胞比， $\mathrm{T} \gamma$ 細胞比

術前の T-細胞比および B-細胞比, $\mathrm{T} \gamma$ 細胞比と乳

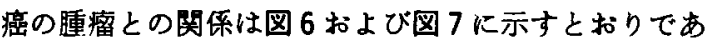
Ђ.

T-細胞比についてみると， $\mathrm{T}_{1} 79.5 \pm 1.6(\%), \mathrm{T}_{2}$ $81.4 \pm 1.4 . \mathrm{T}_{3} 80.3 \pm 4.2, \mathrm{~T}_{4} 75.8 \pm 4.3$ であり, $\mathrm{T}_{1,2,3}$ の間に大差はないか，T、では低値を示した。

B-細胞比についてみると， $\mathrm{T}_{1} 9.9 \pm 2.1$ (\%), $\mathrm{T}_{2}$ 9.6士0.6, $T_{3} 13.0 \pm 3.3, T_{4} 12.8 \pm 1.3$ である. $T_{1,2}$ に差はなく，また $\mathrm{T}_{3,4}$ にも差をみないが, $\mathrm{T}_{1,2}$ に比較し て $T_{3,4}$ の方が高檤を示す傾向を認めた。

$\mathrm{T} \gamma$ 細胞比についてみると， $\mathrm{T}_{1} 7.8 \pm 1.2(\%), \mathrm{T}_{2}$

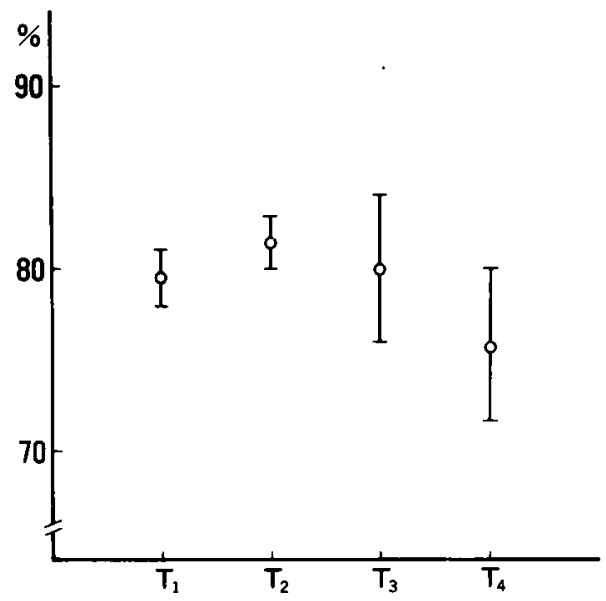

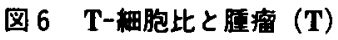

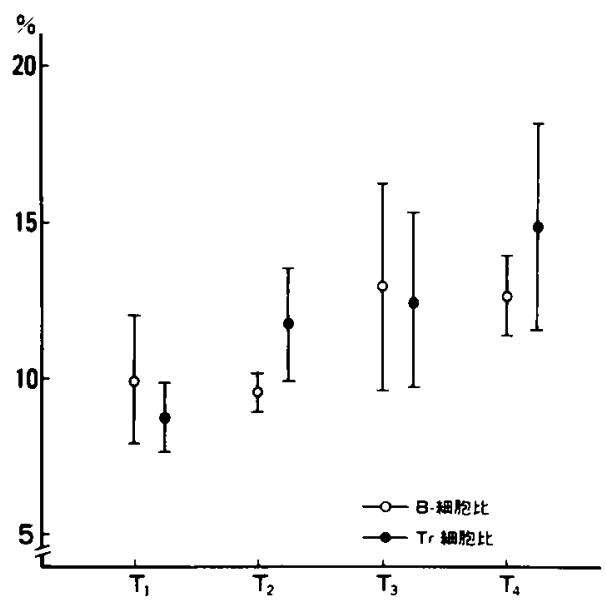

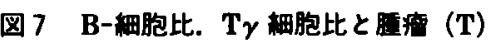

$10.9 \pm 1.8, T_{3} 11.6 \pm 2.8, T_{4} 14.0 \pm 3.3 て ゙ あ り ，$ 腫瘤 が大きくなるにしたがい高値を示す傾向を認めた。

3） PHA 幼若化反応（SI 値）

術前の PHA 幼若化反応の SI 值と乳癌の在瘤との 関係は図 8 に示すとおりである.

$\mathrm{SI}$ 値についてみると， $\mathrm{T}_{1} 218.3 \pm 39.4, \mathrm{~T}_{2} 211.1 \pm$

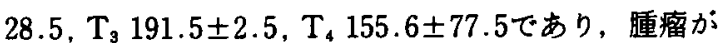
大きくなるにしたがい低下するが， $T_{1,2,3}$ に比較して T、では明らかな低値を示した。

3. 免疫学的パラメーターと組織学的リンパ節䎐移 度 (n) との関係

1）末梢血リンパ球数

術前の末梢血リンパ球数と乳癌の組織学的リンパ節

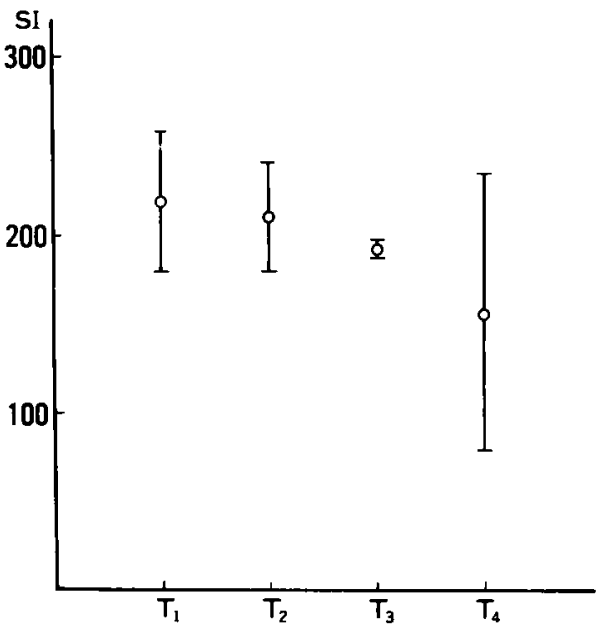

図 8 PHA 幼若化反応（SI 值）と瘇瘤（T）

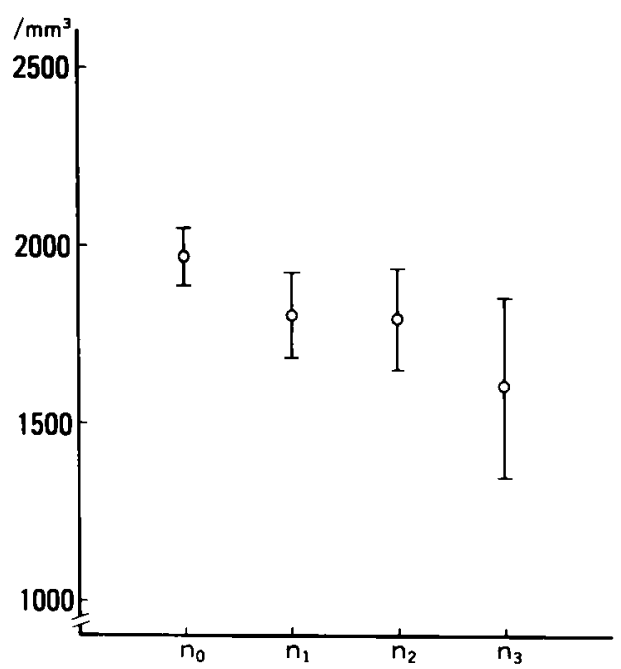

図 9 末梢血リンパ球数 
転移度との関係は図 9 に示すとおりである。

末梢血リンハ球数について組織学的リンパ節転移度 別にみると, $\mathrm{n}_{0} 1,963.9 \pm 71.5\left(/ \mathrm{mm}^{3}\right), \mathrm{n}_{1} 1,810.8 \pm$

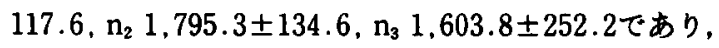
リンパ節転移の払がりにしたがい減少した。

2） T-細胞比および B-細胞比， $\mathrm{T} \gamma$ 細胞比

術前の $\mathrm{T}$-細胞比ょょび B-細胞比, $\mathrm{T} \gamma$ 細胞比と乳 癌の組織学的リンパ節転移度との関係は図10および図 11に示すとおりである. T-細胞比についてみると， $\mathrm{n}_{0}$ $81.9 \pm 0.9(\%), n_{1} 81.2 \pm 2.2, n_{2} 78.6 \pm 2.1, n_{3}$ $75.5 \pm 4.8$ ありり,リンパ節転移の払がりにしたがい低 値を示した.

B-細胞比についてみると， $\mathrm{n}_{0} 8.5 \pm 0.9(\%), \mathrm{n}_{1}$ $8.6 \pm 1.3, \mathrm{n}_{2} 8.7 \pm 0.9, \mathrm{n}_{3} 10.0 \pm 3.0$ であり, $\mathrm{n}_{0.1,2}$ の

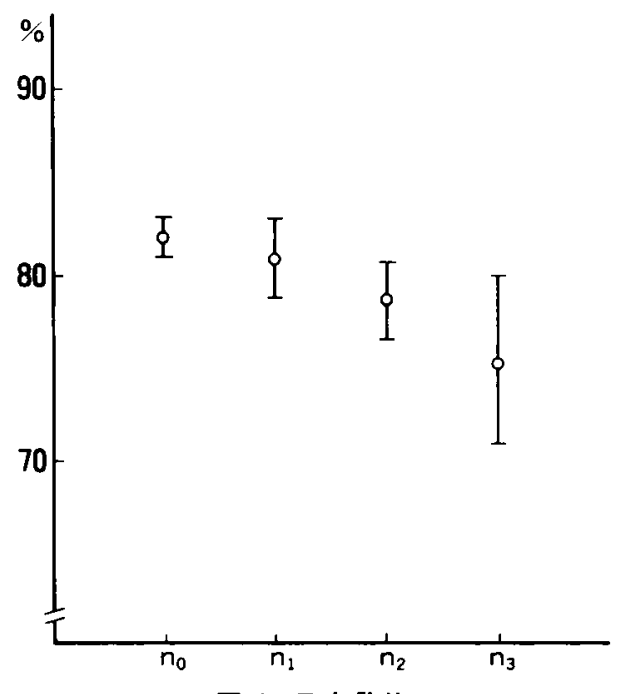

图10 T-細胞比

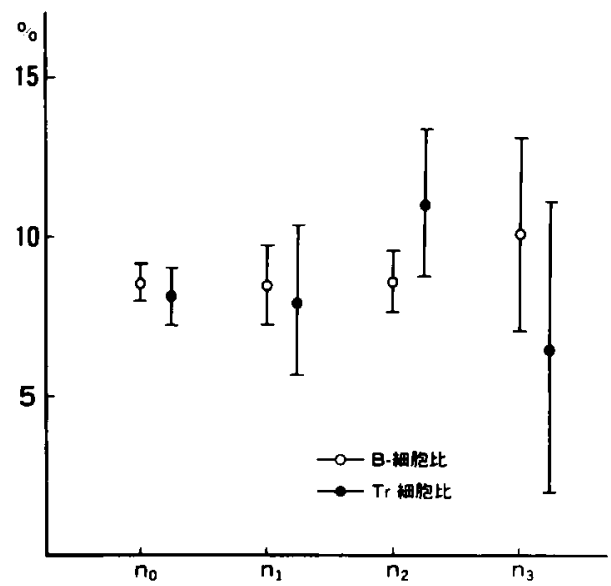

图11 B-細胞比・T $\boldsymbol{\gamma}$ 細胞比
間に大差はないか， $\mathrm{n}_{3}$ ではやや高値を示した。

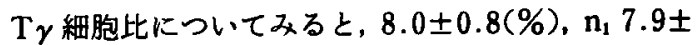
$2.5, \mathrm{n}_{2} 11.4 \pm 2.3, \mathrm{n}_{3} 6.5 \pm 4.5$ である. $\mathrm{n}_{0,1}$ に差はな いが $\mathrm{n}_{2}$ では高値を， $\mathrm{n}_{3}$ ではやや低值を示した。

3) PHA 奻若化反応 (SI 値)

術前の PHA 幼若化反応のSI 值と乳癌の組䋨学的 リンハ節転移度との関係は図12に示すとおりである。

$\mathrm{SI}$ 值についてみると， $\mathrm{n}_{0} 203.5 \pm 16.0 ， \mathrm{n}_{1} 185.6 \pm$ $34.9, \mathrm{n}_{2} 144.8 \pm 44.6, \mathrm{n}_{3} 102.5 \pm 51.5 て ゙ あ り$, リンハ 節転移の払がりにしたがい低下する㑯向を認めた。

4. 免疫学的パラメーターと薏隔転移 (m) との関係

1）末梢血リンパ球数

術前の末梢血リンパ球数と乳癌の遠隔転移との関俰 は図13に示すとおりである。

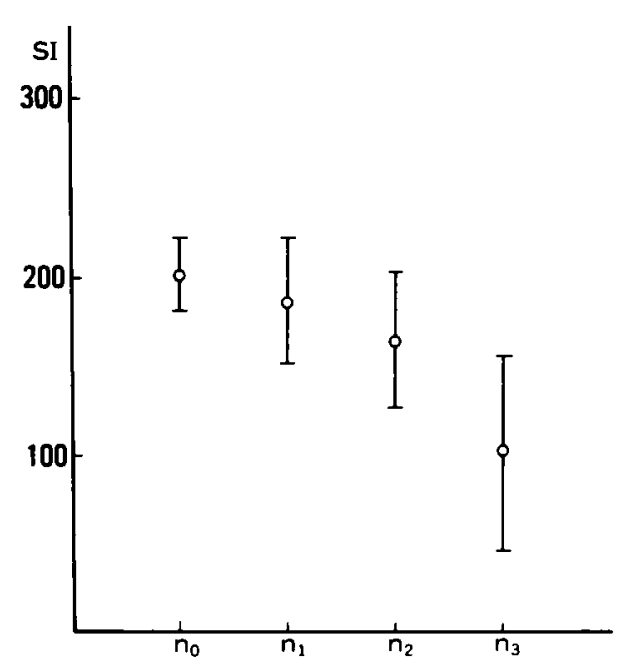

図12 PHA 幼若化反心（SI 住）

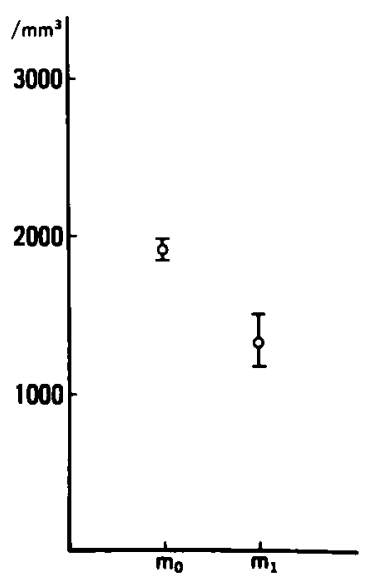

图13 末梢血リンパ球数と这俩输移（m) 
末梢血リンハ球数について迋隔転移の有無の別から みると, $\mathrm{m}_{0} 1.916 .3 \pm 57.0\left(/ \mathrm{mm}^{3}\right), \mathrm{m}_{1} 1,336.6 \pm$ 196.0であり，遠隔転移のあるすのはないすのに比較し て減少していた。

2） $\mathrm{T}$ 一細胞比および B-細胞比, $\mathrm{T} \gamma$ 細胞比

術前の $\mathrm{T}$-細胞比および B-細胞比, $\mathrm{T} y$ 細胞比之乳 癌の迋隔転移との関係は図14に示すとおりである。

$\mathrm{T}$-細胞比についてみると， $\mathrm{m}_{0} 81.7 \pm 0.76(\%), \mathrm{m}_{1}$ $76.0 \pm 4.5 て ゙ あ り ，$ 遠隔転移のあるすのはないものに比 較して低値を示した。

B-細胞比についてみると， $\mathrm{m}_{0} 9.2 \pm 0.7$ (\%), $\mathrm{m}_{1}$ $10.5 \pm 1.3 て ゙ あ り$, 遠隔転移のあるものはないものに比 較してやや高值を示した。

$\mathrm{T} \gamma$ 細胞比についてみると, $\mathrm{m}_{0} 10.1 \pm 1.8(\%), \mathrm{m}_{1}$ $6.8 \pm 3.1 て ゙ あ り ，$ 遠隔転移のあるるのはないるのに比
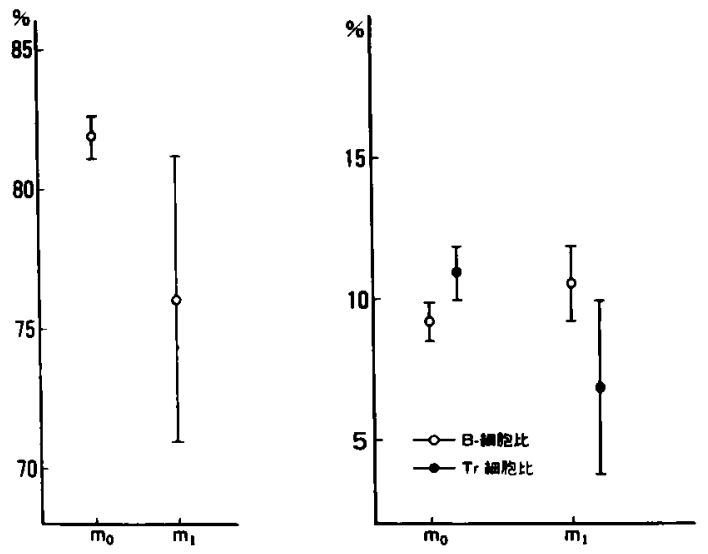

图14 T-細胞比・B-細胞比・ $\mathrm{T} \gamma$ 細胞比と透隔転移 (m)

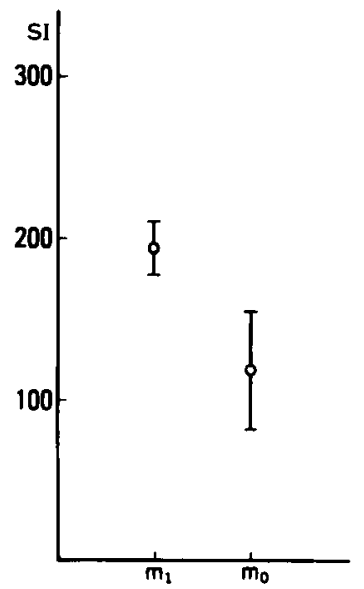

图15 PHA 幼若化反応（SI 值）と速雨転移（m)
較して低値を示した。

3) PHA 幼若化反応 (SI 値)

術前の PHA 幼若化反応の SI 值と乳癌の遠隔転移 との関係は图15に示すと扣りである。

$\mathrm{SI}$ 值についてみると, $\mathrm{m}_{0} 193.8 \pm 15.3, \mathrm{~m}_{1} 118.0 \pm$ 35.5であり，遠隔転移のあるものはないものに比較し て著明に低下した。

第 2 節 術前・術後にわたる T-細胞比, PHA 幼若 化反応（SI 值）の経時的帘動

\section{T-細胞比の経時的变動}

T-細胞比の術前から術後 1 週， 2 週，4 週， 1 年に わたる経時的变動および再発との関保は図16に示すと 扣りである。

進行度別にみると, stage I, II 群では, 術前81.8士

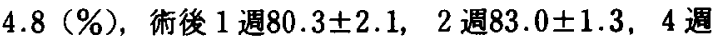
$83.2 \pm 1.2,1$ 年82.3 0.9 であり, 術後 1 週でやや低 下， 2 週で回復， 1 年経過時にはわずかに下降するが 大きな変動を認めなかった。

stage III, IV 群では術前79.9土2.6（\%)，術後 1 週

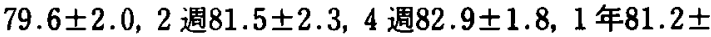
1.2であり， stage I, II 群と同じょらな傾向を諗めた。

また，再発症例は stage I, II 群で83.0 III, IV 群で79.8土1.0であり，非再発症例と比較して 明らかな差は認めなかった。

\section{PHA 幼若化反応（SI 值）の経時的变功}

PHA 幼若化反応の SI 值の術前から術後 1 䓢， 2 週， 4 週， 1 年にわたる経時的変動扰よび再発との関 係は図17に示すとおりである。

進行度別にみると, stage 1,11 群では, 衍前230.6士 27.3 , 訹後 1 週 $150.8 \pm 21.1,2$ 週173.3 $21.8 ， 4$ 週 $136.5 \pm 19.2,1$ 年146.8 14.4 であり，術後 1 週で低 下， 2 週で上昇するが 4 週で再び低下し， 1 年経過時 でやや回復する傾向を認めた。

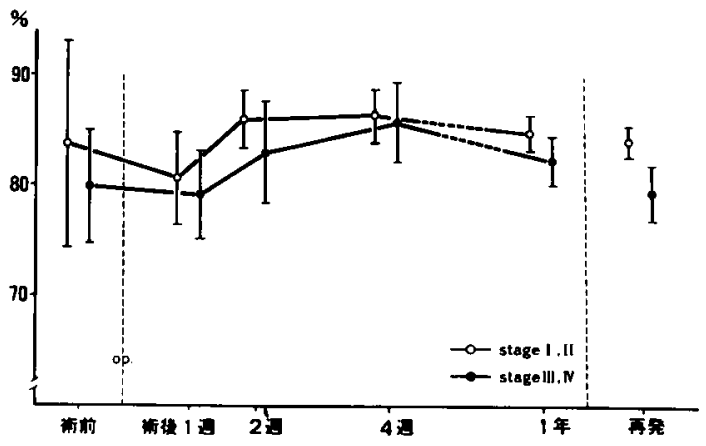

图16 僬行度別にみた T-梱胞比の経時的変動 


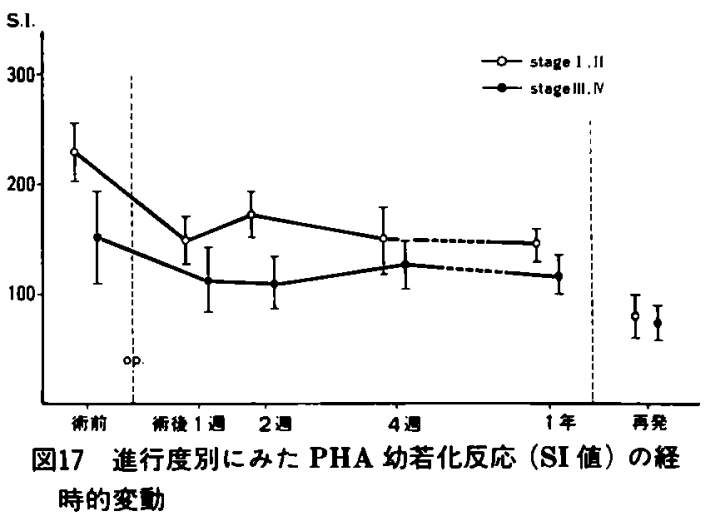

stage III, IV 群では術前152.1土41.2, 術後 1 週

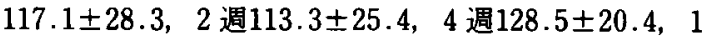
年120.6 17.6 であり, 術後 1 週で低下, 以後回復しな いままに経過した。

また，再発症例は stage I, II 群で80.0 III, IV 群で74.0土18.0であり, 非再発症例に比較して 著明な低下を認めた。

第 3 節 術前・術後にわたる T-細胞比，PHA 幼若 化反応（SI 值）の経時的变動と手術術式

\section{1. $\mathbf{T}$-細胞比の経時的变動と手術術式との関係}

T-細胞比の術前から術後 1 週， 4 週， 1 年にわたる 経時的変動と手術術式との関係は図18に示すと括りで ある。

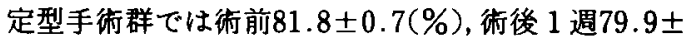

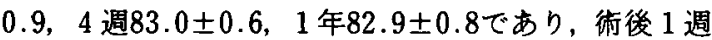
でやや低下， 4 週以後では回復した。

樎小手術群では術前80.3土2.6(\%)，術後 1 週 $84.2 \pm$

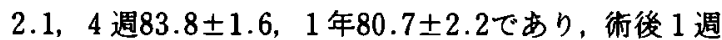
で上昇， 1 年経過時ではわずかに下降した。

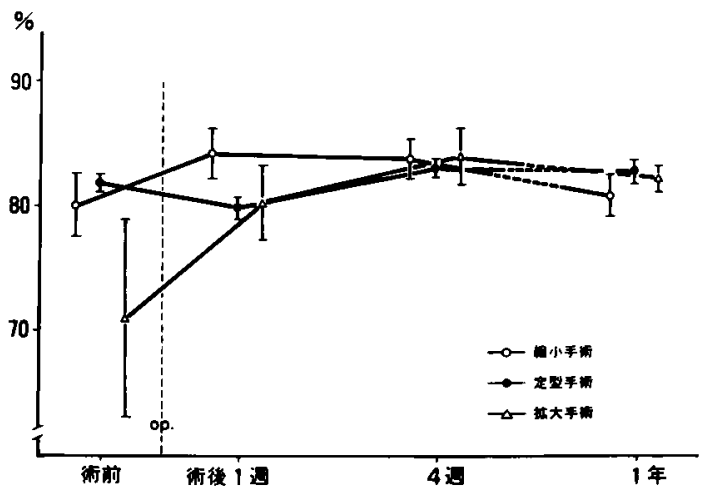

图18 手術式別にみた $\mathrm{T}$-细胞比の経時的変動
払大手術群では術前 $71.0 \pm 8.2(\%)$, 術後 1 週80.7士

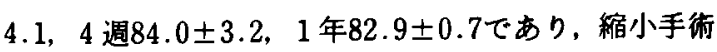
群と同じような傾向を認めた。

また，拡大手術群は定型手術群，縮小手術群に比較 して術前值は低値であった。術後 1 週では定型手術群 では低下するのに反し，樎小手術群，拡大手術群では 上昇し，以後 3 群ともほぼ同値となって経過した。

2. PHA 幼若化反応 (SI 值)の経時的変動と手術術 式との関係

PHA 幼若化反応の SI 值の術前から術後 1 週, 4 週，1年にわたる経時的变動と手術術式との関倸仕图 19に示すとおりである.

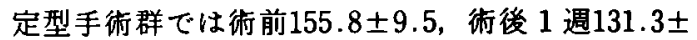

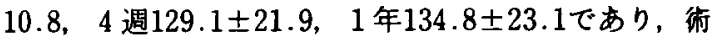
後 1 週で低下, 1 年経過時でやや回復する傾向を認め た。

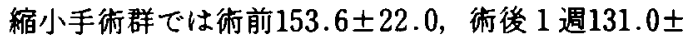

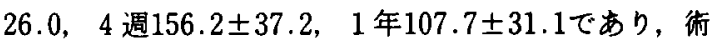
後 1 週で低下， 4 週で回復するが 1 年程過時には再び 低下した。

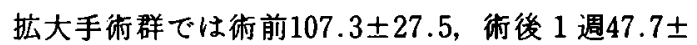
$13.3,4$ 週 $121.7 \pm 21.9,1$ 年 $66.0 \pm 20.3$ であり，術後 1 週で著明に低下， 4 週で回復するが 1 年経過時には 再び低下を認めている。

また，拡大手術群は定型手術群，縮小手術群に比較 して術前值は低下しており，術後1週における低下る 著明であった，一方，縮小手術群は定型手術群，抎大 手術群に比較して術後 4 週における回復が著明であっ た.

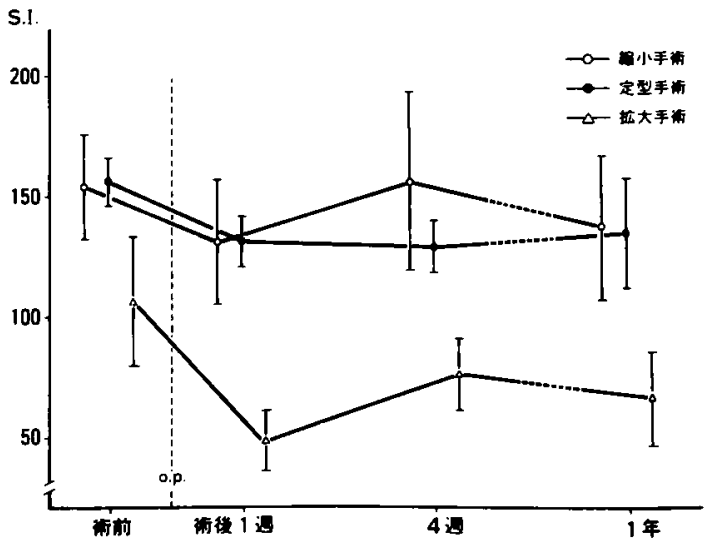

图19手術術式別にみた PHA 幼若化反応（SI 值）の 経時的变動 


\section{第4章考案}

担癌生体に扔いて，自己の癌に対する免疫応答が営 まれることは多くの動物実験によって証明され，また ヒトの癌に执いても Southam ら"の自家移植, Grace ら てきている22) -24).さらにこの腄瘍特異的ともい5べき 免疫反心は，細胞性免疫が主体をなすことす広く認め られた事実である2526).

このような生体の抗腫場性免疫反応を，何らかの物 質により賦活しよ5とする免疫療法は, BCG の有用性

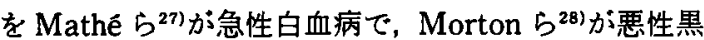
色腫で立証して以来広く臨床応用されるよらになり， 種々の賦活物質やその投与法などに関しても精力的な 検討が重ねられている291-31)。

乳癌の治療においても例外ではなく，手術・化学療 法など既存の治療法に加えて主として非特異的な免疫 療法が行われ4 6)，これらの併用は乳癌治療の原則と されるにいたっている。

この免疫療法の目的は，担癌状態はもとより手術侵

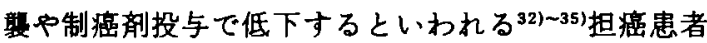
の抗腫湯性免疫反応を賦活し，腫湯抗原に対する免疫 応答を増強させ，遗残した癌細胞あるいは転移・再発 時に出現する癌細胞の破壊を誘導しようというすので ある。

そのためこれを合理的かつ有効に施行し，さらに 臨床効果を追求する指標として，生体のこのような免 疫反応を惹起しうる能力，すなわち，細胞性免疫能を 把握することが重要とされ，多くは非特異的なもので あるが種々のパラメーターを用いた検索がなされてい $る^{(0) \sim 16) 36)}$.

乳癌においても免疫療法を行う以上は，患者の細胞 性免疫能が癌の進行にしたがってあるい恃再発により どのような状態となるのか，また治療によってどう変 化してゆくのか，さらにはどのパラメーターが患者の 免疫能を最す正確に反映するのかを明らかにしておく 必要がある。

そこで，乳癌患者における非特異的細胞性免疫能を 末梢血リンハ球数， $\mathrm{T}$-細胞比， B-細胞比， $\mathrm{T} \gamma$ 細胞比, PHA 幼若化反応の SI 値などをバラかーターとして 進行度別に明らかにした。さらに進行度を規定する 個々の因子についても同じょらに詳細な検討を行っ た.

まず乳癌の $\mathrm{Tnm}$ 病期分類による進行度（stage）上 の関係について検索した。
最初に末梢血リンパ球数であるが, stage I, II, III に 比較して stage IVでは減少がみられている。この末梢 血リンパ球数の測定は, 種タのリンハ球の数を合計し て算定するが，末梢血リンハ球の70－80\%は細胞性免 疫能の担い手である $\mathrm{T}$-リンパ球（T-細胞）であるた め，この数によって患者の細胞性免疫能をある程度推 测しらると考之られている(4). 古江ら ${ }^{371}$ は進行癌では 全般的に减少の傾向がみられるとし，折田 ${ }^{14)}$ ま梢血 リンバ球数の減少は進行癌で多く，予後む不良なるの

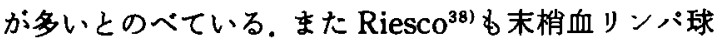
数と 5 年生存率との関保から、リンハ球数の多いもの の予後は良好であり，これは生体に打ける抗腫瘍性の 一つの指標となりらるとのべている。.いずれの報告も 著者と同じ傾向である．本法はその測定法が容易であ ること，また安定した結果がえられることも併せれば， 細胞性免疫能を知る最も簡単なバラメーターであると 思われる。

末梢血リンハ球の T-細胞比では, stage I, II, III に 大差はないが， stage IVでは低下し，リンパ球数とは ぼ同じ傾向がみられている，生体の細胞性免度能の主 体を担らのは T-細胞であり，この T-細胞比について は従来より種々の癌について多くの検索がなされてい る $^{12) \sim 14)}$. 乳癌に関しては, $\mathrm{T}$-細胞比と進行度との間に は相関を認めないとした報告39)るるれるが，多くは 癌患者, とくにその病期の進行したすのでは低下する と報告されている38)40(41). 著者の成績むこれらに一致 するるのであり、T-細胞比はとくに病期の進行したす のに関して有用なパラメーターであると思われる。

末梢血リンパ球の B-細胞比では, 病期の進行にした がって高値となる傾向がみられている。担癌生体では T一紐胞に関係した細胞性免疫能の低下はみられるが， B-細胞の関与する体液性抗体の産生は一般に冒され ないことが多いといわれている.この B-細胞比に関し た諸家の報告では，担癌生体において増加するという すの ${ }^{42}$, 减少するといういの (3)44)，あるいは不変である とするるの45などがあり，一致した見解はみられない． さらに進行度別にみると大浪ら ${ }^{46)}$ は病期の進行にした がいまた予後不良なるのはど B-細胞比は増加の傾向 にあるとのべている，著者の成績では stage I, II に比 較して stage III, IV での増加傾向が認められており, 後者の報告にほぼ一致するむのと考えられる．

末梢血りンパ球の $\mathrm{T} \gamma$ 細胞比では，病期の進行した もので高値を示す傾向がみられた。この $\mathrm{T} \boldsymbol{y}$ 紐胞は主 として抗腫痬性免疫反応を抑制する suppressor $\mathrm{T}$-細 
胞と目されており，進行癌では増加するといわれてい $3^{21)}$. 新保ら ${ }^{47}$ は癌患者の多くで $\mathrm{T} \gamma$ 細胞は増加して いると報告し, 滝(8) は胃癌で, 秋元ら ${ }^{49}$ は乳癌で末梢血 リンパ球の $\mathrm{T} \gamma$ 細胞比は上昇をみたとのべている。著 者の成耫では stage I, II に比較して stage III, IV での 增加がみられており，秋元らと同じ結果であると思わ れる。

末梢血 リンパ球の PHA 幼若化反応の SI 值では, 病 期の進行にしたがって低下がみられるが，とくに stage I, II に比較して stage III, IV での低下が著明と なっている.この PHAによるリンパ球の幼若化反応 は， $\mathrm{T}$-細胞の機能を反映する ${ }^{50)}$ とされ，これも従来か ら種々の癌について多くの挨索がなされてい $3^{91-14}$ 。乳癌に関して服部ら均は汪とんど低下しない とし，菊地ら ${ }^{36}$ は胃癌などに比較すればその程度は小 さいが低下を認めるとし、三輪ら ${ }^{40)}$, 金谷 ${ }^{511}$ は病期の進 行度に逆相関する結果がえられたと報告している。著 者の成績はこのらち, stage III, IV でとくに幼若化反 応の低下がみられたとする三輪ら ${ }^{401}$ の成績に一致して いる.

以上の結果から，乳癌患者に打ける術前の細胞性免 疫能に関して, リンパ球数、 T-細胞比からは stage I, II, III と stage IV の間に, B-細胞比, T $\gamma$ 細胞比, PHA 幼若化反応 (SI 值) からは stage I, II と stage III, IV の間に差がみられている.他方, stage IIIに扎ける T 一細胞比には生体に不利な条件となる suppressor T 一細胞, すなわち $\mathrm{T} \gamma$ 細胞の増加もみられている. 結局, 乳癌の進行度からみた細胞性免疫能は stage I, II と stage III, IV の間で一線が画ざれ，低下が認められる よらに思われる。

ここで担癌生体における細胞性免疫能低下のメカニ ズムについて考えてみたい，一般に生体では免疫担当 細胞としてT-細胞, B-細胞, NK 細胞, マクロフォー ジどが存在し，その各々が独立して，あるいは相互 が密接な関係をもちつつ癌に対する免疫学的な制御機 構を構成しているといわれている、その制御能力がい わゆる細胞性免疫能であると理解できよう．ところが 担癌状態となれば，腫瘍の増大にともない血清中には blocking factor が放出され，また腫瘍抗原は過㮃に産 生され流血中に出現する。そ結果, 免疫担当細胞の 数や比率, 機能などに変調が生じ，制御機構には破綻 が招来されるわけである.この状態が臨床的にはリン ：球数の减少, $\mathrm{T}-$ 細胞比の低下, B-細胞比や $\mathrm{T} \gamma$ 細胞 比の上昇, PHA 幼若化反応 (SI 值)の低下など細胞性
免废能の低下といら形で促えられるるのと思われる。

著者の成績からみれば，乳癌患者におけるこの制御 機構の破糘は, stage III から認められるということが できよう。

このよらな手術前から細胞性免疫能が解析できれ ば, 癌の進行度や予後の推定が可能となり,さらには 低下した症例では破綻した制御機楧を回復させるべく 積極的に免疫療法を施行するなど治療方針をらること すできよ5。ささらに, 治療成績の向上にもつながるも のと考える.

また，末梢血りンパ球の PHA 幼若化反応のSI 值 は, 著者が乳癌に関して検索した各免疫学的ハラメー ターのうち，その進行度とよく相関し，最も有用であ ると思われる．臨床上すべてのパラメーターを測定す る繁雑さを考虑すれば, 乳癌患者の細胞性免疫能を把 握するには本法のみでも十分であると思われる。

つぎに Tnm 病期分頑による進行度を規定する各因 子との関係について検討した。

畽瘤の最大径や拡がりとの関俰では末梢血リンハ球 数, T-細胞比, PHA 幼若化反応の SI 值などは $\mathrm{T}_{1}, \mathrm{~T}_{2}$, $\mathrm{T}_{3}$ に比較して $\mathrm{T}$ 、で減少あるいは低下が認められる. 一方， B-細胞比， $\mathrm{T} \boldsymbol{\gamma}$ 細胞比などは腫瘤が大きくなる にしたがい高値となる傾向がみられる．乳癌の腫瘤の 大きさや拡がりと細胞性免废能との関係を明確にした 報告はないか，著者の主として $T_{4}$ でのみ低下すると いら成績をみれば，腫瘤の大きさは細胞性免疫能に余 り影響を与えないようであり,この $\mathrm{T}$ 、での低下は, む しろ病期の進行に上る全身状態の低下に起因すると考 えられる.

組織学的リンパ節転移度との関係では，末梢血リン 八球数, T-細胞比, PHA 幼若化反応の SI 值などは, リンパ節転移の抎がりにしたがい、减少あるいは低下が 認められる. また, B-細胞比は $\mathrm{n}_{3} て ゙, \mathrm{~T} \boldsymbol{\gamma}$ 細胞比は $\mathrm{n}_{2}$ でやや高值を示している，乳癌のリンパ節転移度と細 胞性免度能との関係を明確にした報告はないが矢川 ${ }^{23)}$ は胃癌においてこの関係を検索し, 転移度と $\mathrm{T}$-細胞 比, PHA 奻若化率には逆相関をえたと報告している. 著者の成績にもこれと同じ傾向がみられており, 乳癌 に怙いてもりンパ節転移の拡がりが細胞性免疫能の低 下に大きく関与しているものと思われる.

遠隔転移との関係では，末梢血リンパ球数， $\mathrm{T}$-細胞 比, $\mathrm{T} \gamma$ 細胞比, PHA 幼若化反応の SI 值などは, とも に $\mathrm{m}_{0}$ に比較して $\mathrm{m}_{1}$ での減少あるいは低下がみられ る. また B-細胞比は逆に $m_{1}$ でやや高値を示してい 
る.乳癌の遠隔転移と細胞性免疫能との関係を明確に した報告は少ないか，Stein ら52)は乳踟において， Braun ら ${ }^{53)}$ は乳癌および肺癌に拈いて遠隔転移のあ るものはないすのに比較して著明な細胞性免疫能の低 下をみたとのべており，著者の成績もこれらに一致す るすのと思われる。

以上の結果から, 㾘瘤径や払がり,リンパ節転移度, 遠隔転移など乳癌の進行度を規定する各因子と細胞性 免疫能との関係をみると，腫瘤の増大な皮店や胸郭一 の浸潤などをみない限り細胞性免度能に影翌はなく， 他方, リンパ節転移の払がりは細胞性免疫能の低下に 大きく関与することが明らかとなった，乳癌の進行に ともな5細胞性免度能の低下は，このリンパ節転移で みられる低下が主体をなするのと思われる。

また， $\mathrm{T}$ のすの， $\mathrm{m}_{1}$ のものに著明に細胞性免疫能の 低下がみられるが，これは病期の高度な進行による全 身状態の低下に起因すると考えた方が妥当であるよ に思われる.

つついて細胞珄免疫能の術前・術後にわたる経時的 変動について, stage I, II 群と stage III, IV 群に分け て検索した。

まず，丁一細胞比をみると，両群とも術後 1 週でやや 低下， 2 週で回復し以後 1 年まで大きな変動は認めら れない：堆行度からみて当然であるか，いずれの 時期においても stage III, IV 群は stage I, II 群に比較 して低值を示している. 乳癌患者の T-細胞比を術前・ 術後にわたり䅅時的に測定した報告ははいか， T一細胞 数では，菅ら ${ }^{54)}$ は術後 1 週で低下するとし，北村ら 551 は 術後 2 週で低下し，約 3 カ月後に回復をみたとのべて いる、T-細胞比と T-細胞数に慜密な相関はないが，著 者の成績における衍後 1 週での低下は菅らの成績に一 致する傾向がうかがわれ，また 2 週での回復は北村ら の成績に比较してかなり早いよ5に思われる。

ついで, PHA 幼若化反応の SI 值をみると, stage I, II 群では術後 1 週で低下， 2 週でやや回復するが 4 週 で再び低下し，1年でわずかに回復がみられている. 他方, stage III, IV 群では術後 1 週の低下は同じであ るが，それ以後は横這い状態で，回復は認められない。 また， T一細胞比と同しく，いずれの時期においても stage III, IV 群は stage I, II に比較して低い值を示し ている、釈癌患者のSI 值を著者のごとく術後 1 年まで 释時的に測定した報告は少ないが，北村ら 週で有意に低下するとし，稲本ら ${ }^{56)}$ は術媵 1 週で低下， 2 週以後は回復する傾向をみたとのぺている，著者の stage I, II における成瞔は稲本らの成瞔 ${ }^{56)} に$, stage III, IV に拈ける成績は北村ら ${ }^{55)}$ の成績に近いように思 われる.

このように細胞性免疫能が变動する原因について, 術後 1 週における低下は手術・麻酔・投与蓧剤などの いわゆる手術侵襲によるものであり，4 週以後の低下 はMMC, FT-207など制癌昘の影暂による。のと推察 できるが，またここで，T-細胞比の回復が早いこと， 術後 1 年の SI 値で stage I, II 群は回復傾向をみるこ と, stage III, IV 群も大きく低下を認めないことなと 事実も認められている. 北村 ${ }^{551}$ の術後補助化学療法 施行例では紐胞性免度能は大巾に低下するとの報告を 考え併せれば，免疫療法の併用効果が認められる成績 であると思われる．またこの奻果をバラメーターの变 動からみれば，免疫療法は術前の細胞性免疫能の良好 な stage I, II 群の方がより有効であるとす解釈できよ 5.

つぎに再発と細胞性免疫能との関係について検索し た. 再発症例における T-細胞比, SI 值を 1 年経過した 非再発症例のそれと比僌すると，T一細胞比に明らかな 差はないが，SI 值では明らかに低下が認められてい る.この再発症例には全身状態に余り変化のない局所 再発例も含まれるため, T-細胞比を変化させるにはい たらず,より鋭敏なSI 值にのみ影整をみたすのと思わ れる、森本ら ${ }^{57)}$ 長期制癌剂投与時の免疫学的ハラ メーターの変動から PHA 幼若化反応の SI 值を細胞 性免疫能をすっとむ鋭敏に反映するとのべている. 著 者の成績からもこの SI 值は, 乳癌患者の細胞性免疫能 や臨床経過をよく反映し，術後経時的に测定すれば再 発予知の指標ともなりらると考える。

最後にこの手術侵就と細胞性免废能の関係につい て, 定型手術, 樎小手術, 払大手術の手術術式の別か ら検索した。

まず T-細胞比をみると, 定型手術群では術後 1 週 でやや低下，以後は回復をみ，樎小手術群，抬大手術 群では 1 週でやや上昇, 以後はわずかな低下をみると いうまちまちな成績となっている，手術侵盤の影敕が 最す強い術後 1 週において，定型手術群にわずかな低 下がみられるにすぎず, 乳癌の手術侵襲はT一細胞比 には明らかな影醘を与えないように思われる。

一方, PHA 幼若化反応のSI 值をみると, 各群とも 術後 1 週で低下し， 1 年経過時には定型手術群にわず かな回復, 縮小手術群, 払大手術群には低下傾向がみ られている.乳癌の手術侵襲により, 術後 1 週の SI 値 
には明らかな低下が認められ，またそれは定型手術群， 樎小手術群に比較して扗大手術群で影著なるのとなっ ている.この执大手術群でとくに低下する原因は，执 大手術は病期が進行して細胞性免疫能の低下した症例 に行われる場合が多いことも一因であろらが，主とし てその手術侵襲の大きさを反映したものと思われる。

物理的な手術唚慗はそれ自体，免疫能を一過性に低 下させるといわれている58159).これに関して, 著者の成 績ではT一細胞比では明らかではなかったが，より鋭 敏なパラメーターであるSI 值では認められている。こ の低下をはっきり諗識することが, 補助免废化学療法 を行ららえで重要であると考える.

以上の検討から，乳癌の治療にはまず術前の細胞性 免疫能を十分に把握することが必要であり，ついで手 術侵襲や長期にわたる制癌剤投与のそれに対する影響 を考虑した免疫㞠法の併用が重要であろ5．手術術式 や手技は限界まで発達し，制癌剂もこれ以上の効果は 期待できない現在,このような患者の細胞性免㡯能の 低下を最小限にくい止める補助療法こそが治療成績を 向上させ ると考える。

\section{第 5 章 結 語}

末梢血リンパ球数， $\mathrm{T}$-細胞比， B-細胞比， $\mathrm{T} \boldsymbol{\gamma}$ 細胞 比, PHA 幼若化反応の SI 值などをパラメーターとし て乳癌患者の非特異的な細胞性免疫能を検索し，つぎ のよらな結論を得た。

1）術前の末梢血リンハ球数は stage I, II, III に比較 して, stage IVで减少した。

2）術前の末梢血リンハ:球の T-細胞比は stage I, II, III に比較して stage IVで低下した。

3）術前の末梢血リンパ球の B-細胞比， $T \boldsymbol{y}$ 細胞比 は病期の進行にしたがい上昇し, stage I, II に比較し て stage III, IVでは高値を示した。

4）術前の末梢血リンパ球の PHA 幼若化反応の SI 値は病期の進行にしたがい低下した。

5）以上のハラォーターからみた術前の細胞性免疫 能は, stage I, II に比較して stage III, IVでは低下し た.

6) 術前の末梢血リンパ球数, T-細胞比, PHA 幼若 化反応の SI 值は $T_{1}, T_{2}, T_{3}$ に比較して $T_{4}$ で減少あ るいは低下した。

7）術前の末梢血リンパ球の B-細胞比， $T \boldsymbol{y}$ 細胞比 は $\mathrm{T}_{1}, \mathrm{~T}_{2}$ に比較して $\mathrm{T}_{3}, \mathrm{~T}_{4}$ では高值を示した。

8）術前の末梢血リンパ球数, T-細胞比, PHA 幼若 化反応の SI 值は,リンパ節転移の拡がりにしたがい减
少あるいは低下した。

9）術前の末梢血リンバ球の B-細胞比は $n_{3} て ゙, T \gamma$ 細胞比は $\mathrm{n}_{2}$ でやや高値を示した。

10）術前の末梢血リンパ球数， $T$-細胞比， $T \boldsymbol{\gamma}$ 細胞 比，PHA 动若化反応のSI 值は $\mathrm{m}_{0}$ に比較して $\mathrm{m}_{1}$ て 減少あるいは低下した。

11）術前の末梢血リンハ球のB-細胞比は $m_{0}$ に比 較して $\mathrm{m}_{1}$ で高値を示した。

12）以上の進行度を規定する各因子とハランメーター との関俰から,リンハ節転移の払がりが細胞性免疫能 の低下にもっとす関与することが示唆された。

13）末梢血リンハ球の PHA 幼若化反応の SI 値は 細胞性免疫能の動向や臨床経過を放鋭敏に反映 し，再発予知の指標とむなりうる。

14）手術侵襲により細胞性免疫能は抑制され，その 低下は定型手術，樎小手術に比較して扗大手術群で著 明であった。

（稿を終わるにあたり，御指導，御校閲を睗った体原宣教 授,ならびに本研究に直接御指复いたたいた暒原哲郎教授， 小川健治講師, 芳賀酸介講師, また御協力いたたいた東京女 子医科大学第二病院外科の諸兄に心より感謝する。

本論文の要旨は第34回乳癌研究会, 第19回日本癌治療学 会, 第35回乳癌研究会, 第44回日本臨床外科医学会総会にお いて発表した.)

\section{文献}

1）深見敦夫：乳癌手術療法最近の䞶勢。大胸筋保存 乳房切断術 Modified radical mastectomy. 中心 として, 手術, 32：1177-1186, 1978.

2）泉雄 勝：乳癌の外科治療，手術, $32: 1187$ $-1193,1978$.

3）渡辺弘，金杉和男，山本浩他：乳癌の外科治 療, 手㭪, 32：1195-1204, 1978.

4）酒井克治, 藤本幹夫：乳癌術後の補助化学寮法, 癌 と化学療, $7: 2083-2096,1980$.

5）泉雄 勝：乳癌，臨床と研究，55：61-66, 1978.

6）芳賀陽子，小川健治，芳賀駤介他：乳癌患者におけ る術前・術後の細胞性免疫能一補助㞠法之の成連 から一, 日癌治誌, $16: 1054 ， 1981$.

7) Southam, C.M. and Moore, A.E. : Induced immunity to cancer cell hemografts in man. Ann. N.Y. Acad. Sci., 73 : 635-653, 1958.

8) Grace, J.T. and Kondo, T.: Investigations of host resistence in cancer patients. Ann. Surg. $148: 633-641,1958$.

9) 谷内 昭, 今井浩三, 阿部弘：癌患者の免疫能, 
臨床免疫，6:1005-1013，1974。

10）螺良英郎, 矢田健太郎, 小川紘一他：癌患者免疫能 の診断ハランーター, 癌と化学療法, 4:733-742, 1977.

11）槣一郎：癌患者の免疫能, 癌の臨床, 24 ： $378-385,1978$.

12）小川一諴, 井上雄弘：In vitro ハララメーター- 癌の 臨床, $24: 477-487,1978$.

13）矢川裕一：消化器癌よりみた胆癌生体の細胞性免 疫能に関する研究, 東京女子医科大学雑誌, 50 ： $842-862,1980$.

14）折田蓔三：瘦患者の免疫機能, 臨床免疫, 14 ： $580-589,1982$.

15）第30回乳癌研究会：乳癌と免疫に関するフンケー ト，日癌治誌。15：1058-1063，1980.

16）服部孝雄, 中野 章, 峠哲哉他：乳癌と免疫，臨 床医, $6: 1622-1624,1980$.

17）乳癌研究会編：臨床・病理乳癌取扱い規約. 第 6 版, 金原出版, 東京, 1981.

18）辻公美：比重遠心法によるリンバ球の分離 (conray ficoll 法)，兔度実検操作法 A，443-446， 日本免废学会編, 金沢, 1975.

19）埛 武彦, 吉田明子：ヒトの T細胞， B-細胞の測 定 (改良法)。免疫実験操作法 A，455-462，日本 免疫学会編，金讯， 1975.

20）楿 武彦：T，B 細胞算定のための口ゼット形成 試釦, 臨床検查, $23: 651-659,1979$.

21）新保敏知, 矢田純一, 中川俊郎：七トIgG-Fc Receptor 陽性 Tリン八球の検出法と各種疾患に おける変動, 臨床免疫, 9:141-144, 1977.

22) Friedman, H. and Southam, C.M. Ed.: Internation conference on immunology of cancer. Ann. N.Y. Acad. Sci., $00: 276,1976$.

23）小林 博, 霞 武彦編：腫場免疫学. 朝倉書店, 東 京, 1974.

24）山村雄一他監修, 藤井源七郎他編：人癌と免疫一そ の基礎と臨休一ライフサイエンス社, 東京, 1976.

25）菊地浩吉: 癌免疫と $\mathrm{T}$ 細胞, 臨床科学, 11 ： 86-97, 1975.

26）菊地浩吉：癌特異抗原と胆癌生体の細胞性免疫 能, 日本臨床, $34: 1233-1249,1976$.

27) Mothè, G., Amiel, J.L., Schwarzenberg, L., et al. : Active immunotherapy for acute lymphoblastic leukemia. Lancet, 1: 697-699, 1969.

28) Morton, D.L., Eilber, F.R., Molmgrem, R.A., et al.: Immunological factors which influence response to immunotherapy in malignant melanoma. Surgery, $68: 158-164,1970$.

29）螺良英郎：癌免疫療法と診断バラメーター一現状 に扣ける比判と考察一, 臨床外科, $33: 1365$ $-1371,1978$.

30）折田蓝三：外科手術と免疫療法, 癌と化学療法, $5: 1153-1159,1978$.

31）井口 瀿, 服部孝婎編 : 癌の免度化学療法. 南山 堂, 東京, 1980 .

32）白倉良太, 山崎芳郎, 門田康正他：手術侵褧之免疫 機能 I. 術後の一週性免疫機能低下, 臨床免度, 14 ： $331-340,1982$.

33) Slade, M.S., Simmons, R.L. and Yunis, E. : Immunodepression after major surgery in normal patients. Surgery, 78: 363-372, 1975.

34) Riddle, P.R. and Berenbaum, M.C. : Postoperative depression of the lymphocyte response to phytohaemagglutinin. Lancet, $1: 746-748,1967$.

35）螺良英郎，矢田健太郎，富永害治：制癌剂と免疫 能, 癌の臨床, $24: 386-394,1978$.

36）菊地浩吉，井口進：細胞性免疫異常および不全

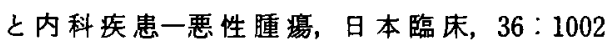
-1017, 1978.

37）古江尚, 込田輝夫, 大山祐子他：免度学的ハラ メータ一の研究. 第 1 報：末梢リンハ球数，ならび K $\mathrm{T}$ 細胞数(治療効果判定の基礎資料)，癌之化学 療法, 5：935-947, 1978.

38) Riesco, A.: Five-year cancer cure. Relation to total amount of peripheral lymphocytes and neutrophils. Cancer, $25: 135-140,197$.

39) Nemoto, T., Han, T., Minowa, J., et al.: Cellmediated immune status of breast cancer patients. Evaluation by skin test, lymphocyte stimulation and counts of rosetteforming cells. J. Natl. Cancer Inst., $53: 641-645,1974$.

40）三輪怒昭, 山崎泰宏, 黒瀬 康他：乳癌患者の細胞 性免疫能々免疫療法, 日臨外医会誌, $41: 238$ $-244,1980$.

41) Whitehead, R.H., Thatcher, J., Teasdale, C., et al.: $T$ and $B$ lymphocytes in Breast cancerstage relationship and abrogation of $T$ lymphocyte depression by enzyme treatment in vitro. Lancet, 2 : 330-333, 1976.

42) Malka, S., Oon, C.J. and Hobbs, J.R.: Excess IqD bearing lymphocytes in patients with 
malignant melanoma. Br. J. Cancer, $30: 379$ $-381,1974$.

43) Ezdinli, E.Z., Simonson, K.L. and Smith, R.A. : Comparison of the effects of single versus multiple agent chemotherapy on lymphocytes assayed by rosette technique. Cancer, $42: 2234$ $-2243,1978$.

44) Pritchard, D.J., Ritts, R.E., Jaylor, W.F., et al. : A prosprospective study of immune responsiveness in human melanoma. 1. Assessment of initial pretreatment status with stage of disease. Cancer, $41: 2165-2173,1978$.

45) Koperszytych, S., Reykollah, M.T., Miki, S.S., et al.: Cell mediated immunity in patients with carcinoma. Cancer, 38: 1149-1154, 1976.

46）大浪更三，猪特俊，西貞隆他：末期癌患者の BCG 免疫㞠法と細胞性免疫能と対する検討，臨床 免疲， $12 ： 384-392 ， 1980$.

47）新保敏和，矢田純一，日正井歌子他：悪性固型䏦場 患者におけるIgG·Fcレヒブター陽性 T 細胞の意 義について，臨床免疫， 9:487-493，1977.

48）滝 正憲：消化器癌患者における IgG-Fcレセブ 夕一陽性 $\mathrm{T}$ 細胞の検討, 日癌治誌， 7:720-727, 1982.

49）秋本実，丹正義，石井样他：乳癌患者におけ る TG 細胞の湌討, 臨床免疫, $12: 728-734,1980$.

50) Shortman, K.M., Byrd, W.T., Cerottini, J.C., et al. : Characterization and separation of mouse lymphocyte subpopulations responding to phytohemagglutinin and pokeweed mitogen. Cell Immunilogy, 65 : 24-40, 1973.
51）金谷 隆：萿患者における細胞性免疫能に成する 研究。第 1 編。癌患者末梢リンハ:球の PHA 奻若化 現象について，札蜆医誌，43：48-59，1974.

52) Stein, J.A., Adler, A. and Efraim, S.B.: Immunocompetence, immunosuppression and human breast cancer. 1. An analysis of their relationship by known parameters of cellmediated immunity in well-defined clinical stage of disease. Cancer, 38: 1171-1187, 1976.

53) Braun, D.P. and Harris, J.E.: Relationship of leukocyte numbers, immunoregulatory cell function and phytohemagglutinin responsiveness in cancer patients. J. Natl. Cancer Ins t., 67: 809-814, 1981.

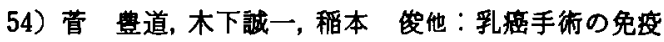
能に及注寸影算，日癌治誌，15：1049，1980。

55）北村正次，富永 健，酒井忠昭他：乳虚および胃癌 患者における免疫能一とくに乳患患者に対する治 療と免疫能一, 日臨外医会誌, 41：434-442, 1980.

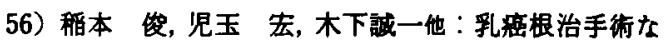
らびに併用療法の免疫能に及ぼす影幚の梌索，日 癌治誌, $14: 932,1979$.

57）森本 健, 上田隆美, 平尾 智他：乳癌の補助化学 療法と免疫，日癌治誌，14：934，1979。

58) Park, S.K., Brody, J.I., Wallage, H.A., et al.: Immunosuppressive effect of surgery. Lancet, 9: 53-55, 1971.

59) Vose, B.M. and Moudgil, G.C. : Effect of surgery on tumor-directed leucocyte responses. $\mathrm{Br}$. Med. J., 1 : 56-58, 1975. 